\title{
PENDIDIKAN KEAGAMAAN PADA KOMUNITAS ANAK JALANAN
}

\author{
Wahid Khozin
}

\begin{abstract}
Street children are the unlucky society socially and economically. They are alive to decorate the down town in several of its activity. In clean, orderly and secure city, the appearance of street children who are growing bigger is estimated as the disturber. Of course, they bave the same right with other child permanently. They have a right in order to get the feasible right, mainly correctly and feasible religion education. But, the religion education for street children is not ever known yet. This research tries to describe the religion education of the street children.
\end{abstract}

Keywords: religion education of street children

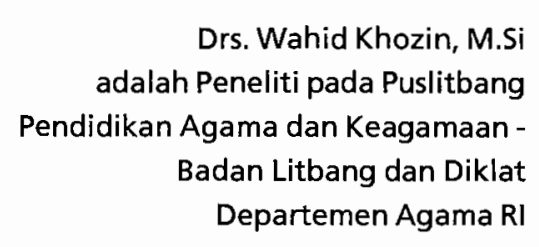

Drs. Wahid Khozin, M.Si

Departemen Agama RI

Keywords. relugion education of street children 
Dan masih banyak lagi isu pendidikan termasuk pendidikan gratis, pendidikan murah sampai pendidikan berstandar internasional. Di balik isu-isu di atas, masih ada sederet keprihatianan yang juga memerlukan perhatian dunia pendidikan. Salah satu isu yang mulai diketengahkan adalah isu tentang pendidikan yang sulit dijangkau, baik secara geografis (daerah terpencil), psikologis (anak cacat), maupun sosial (anak jalanan).

Tetapi, terlepas dari seluruh isu yang mengemuka, kita sebaiknya kembali pada kesepakatan bersama yang tertuang dalam peraturan perundangan. UUD 1945 Amandemen, khususnya pasal 31 Ayat (1) dan (2), secara jelas tidak membedakan antara satu warga negara dengan warga negara lainnya dalam memperoleh pendidikan. "Tiaptiap warga negara berhak mendapat pengajaran". "Pemerintah mengusahakan dan menyelenggarakan satu sistem pengajaran nasional, yang diatur dengan undang-undang". ${ }^{1}$ Statemen perundangan tersebut relevan dengan rumusan Visi Indonesia ke Depan atau lebih populer disebut Visi Indonesia 2020, khususnya terkait dengan sumber daya manusia yang bermutu. "Tantangan dalam pengembangan sumber daya manusia yang bernutu adalah terwujudnya sistem pendidikan yang berkualitas yang mampu melahirkan sumber daya manusia yang andal dan berakhlak mulia, yang mampu bekerja sama dan bersaing di era globalisasi dengan tetap mencintai tanah air. Sumber daya manusia yang bermutu tersebut memiliki keimanan dan ketakwaan serta menguasai ilmu pengetahuan dan teknologi, memiliki etos kerja, dan mampu membangun budaya kerja yang produktif dan berkepribadian."2 Lebih tegas lagi, Undang Undang No. 20 Tahun 2003 tentang Sisdiknas menyatakan bahwa setiap warga negara mempunyai hak yang sama untuk memperoleh pendidikan yang bermutu (1) Warga negara yang mempunyai kelainan fisik, emosional, mental, intelektual dan/atau sosial berhak memperoleh pendidikan layanan khusus (2) Warga negara di daerah terpencil atau terbelakang serta masyarakat adat yang terpencil berhak memperoleh pendidikan layanan khusus. ${ }^{3}$

\footnotetext{
1 Undang-Undang Dasar Negara Republik Indonesia Tahun 1945 (Amandemen), Pasal 31 ayat (1) dan (2)

${ }^{2}$ Lihat Ketetapan Majelis Permusyawaratan Rakyat Republik Indonesia Nomor VII/MPR/2001 Tentang Visi Indonesia Masa Depan, Sekretariat Jenderal MPR RI, 2006

${ }^{3}$ Statemen ini tertuang dalam UU No 20 Tahun 2003 tentang Sisdiknas Bab 4, Hak dan Kewajibab Warga Negara, Pasal 5 Ayat 1 - 3
} 
Jika kita konsisten dengan ketetapan Undang-undang dan visi 2020 tersebut, salah satu jalan yang paling pertama harus dilalui adalah dengan memberikan pendidikan kepada semua warga negara tanpa kecuali. Tetapi, jalan ini penuh dengan tikungan tajam terutama ketika berhadapan dengan perubahan sosial yang terus menerus terjadi. Perubahan sosial, terutama yang disebabkan oleh pembangunan dan modernisasi, tidak selalu bergerak linier dengan rumusan formal yang diidealkan. Ketimpangan mengiringi proses pembangunan dan modernisasi baik dalam sektor ekonomi maupun sosial. Pada sektor ekonomi, prioritas diarahkan pada pembangunan industri-industri besar padat modal dan industri besar yang mempekerjakan buruh murah. Pada sektor sosial, kelihatan dengan jelas kesenjangan antara kota dan desa. Kota di satu sisi dijadikan tempat pembangunan industri sementara desa sebagai basis sektor pertanian, kurang mendapat perhatian, sehingga sektor pertanian semakin terpuruk dalam kerangka persaingan dan pemenuhan kebutuhan dasar. ${ }^{4}$ Dampaknya, kota-kota besar menjadi daya tarik bagi sebagian besar masyarakat dengan iming-iming kemudahan memperoleh pekerjaan dan kemewahan. Ini yang kemudiam menggiring terjadinya gelombang urbanisasi besar-besaran masyarakat desa guna menggapai gemerlapnya kota itu. Pada waktu yang sama, kondisi ini tidak diimbangi dengan penyediaan lapangan kerja yang memadai terutama bagi urban baru yang mayoritas berpendidikan rendah. Maka, yang terjadi bukan lahirnya sebuah masyarakat sejahtera perkotaan, tetapi orang-orang miskin baru, masyarakat rentan dan masyarakat tanpa tempat tinggal (homeless society). Masyarakat demikian, diduga kuat menjadi embrio lahirnya anak jalanan perkotaan. Kesimpulan senada dikemukakan Aswab Mahasin "suatu hal yang agaknya umum diterima para penulis bahwa kotalah yang merupaklan tempat asal mula menggelandang".

Idealnya, anak jalanan, yang juga terlahir sebagai anak bangsa tersebut, mendapat pemenuhan pendidikan baik pendidikan umum

\footnotetext{
${ }^{4}$ Dalam kaitan kesenjangan akibat pembangunan, dijelaskan dengan baik oleh Andrinof A Chaniago. 2001. Gagalnya Pembangunan Kajian Ekonomi Politik terhadap Akar Krisis Indonesia, LP3ES. Menurut Andrin of ada tujuh ketimpangan yang diwariskan Orde Baru; ketimpangan penyebaran asset di kalangan swasta, kesenjangan ekonomi antar sector, kesenjangan antar wilayah, ketimpangan antar sub wilayah, kesenjangan antar golongan sosial ekonomi, kesenjangan pembangunan diri manusia Indonesia dan ketimpangan desa-kota.
} 
maupun pendidikan keagamaan. Kiranya, hanya dengan pendidikan bisa membekali mereka keterampilan, pengetahuan dan agama untuk menjalani kehidupan dalam masyarakat, menentukan pilihan hidup, serta bekal berkompetisi dengan kelompok masyarakat lainnya. Namun, masih belum diketahui dengan pasti bagaimana anak jalanan memperoleh pendidikan secara memadai, terlebih lagi pendidikan keagaman. Maka, penelitian ini dengan menggunakan studi kasus ingin mennggali sejauh mana praktek pendidikan agama dan keagamaan tersebut pada anak jalanan perkotaan.

Secara khusus penelitian ini bertujuan untuk mengetahui dan mendeskripsikan tentang :

1. Profil anak jalanan perkotaan pada lokasi penelitian;

2. Bentuk-bentuk pendidikan keagamaan yang diperoleh anak jalanan;

3. Lembaga apa saja dan siapa saja yang telah memberika pendidikan keagamaan pada anak jalanan;

4. Pengalaman pendidikan keagamaan pada anak jalanan.

Penelitian ini dilakukan di sebelas propinsi, yaitu Sumatera Utara, Sumatera Barat, Sumatera Selatan, Kalimantan Selatan, Banten, Jawa Barat, DI Yogyakarta, Jawa Tengah, Jawa Timur, Nusa Tenggara Brat, dan Sulawesi Selatan. Pengumpulan data dilakukan dengan menggunakan beberapa teknik; 1) Studi kepustakaan, digunakan untuk menggali konsep, teori pendukung dan referensi yang ada kaitannya dengan masalah pokok penelitian. 2) Wawancara untuk memperoleh data informan secara langsung, dilakukan dengan dua cara; formal dan informal. Wawancara formal adalah peneliti melakukan wawancara dengan terlebih dahulu memberitahukan kepada informan bahwa akan dilakukan wawancara. Sedangkan wawancara informal akan dilakukan kapan saja ketika peneliti menemukan informan dan bisa tidak memberitahukan terlebih dahulu kepada informan. 3) Pengamatan; diarahkan untuk menggali data yang tidak ditemukan dalam wawancara yang berupa tindakan, kebiasaan dan perilaku lainnya dari informan.

\section{KAJIAN PUSTAKA Anak Jalanan}

Istialh anak jalanan mulai digunakan pada awal 1990-an ketika Childhope dan Yayasan Kesejahteraan Anak Indonesia (YKAI) melakukan penelitian tentang kelompok gelandangan anak. Dan kelompok inilah yang disebut anak jalanan. Penggunaan istilah anak jalanan diperkuat 
dengan keberadaan Lembaga Swadaya Masyarakat (LSM) yang tergabung dalam Konsorsium Anak Jalanan Indonesia. Pemilihan nama Konsorsium ini sekaligus "meligitimasi" penggunaan istilah anak jalanan di Indonesia secara luas.

Akan tetapi, studi tentang anak jalanan di Indonesia sudah dirintis sejak tahun 1980-an di kota besar, seperti Jakarta (Aan T Subhansyah, dkk). Studi selanjutnya, yaitu tahun 1993, Laboratorium Antropologi Universitas Indonesia bekerja sama dengan bagian Penelitian dan Pengembangan Sosial Departemen Sosial melakukan studi di empat kota : Jakarta, Cirebon, Bandung dan Semarang. Studi tersebut lebih difokuskan pada pencarian sebab kenapa anak jalanan hadir. Di samping untuk mencari landasan bagaimana mengatasi anak jalanan. Kecenderungan lain adalah, mengkaji program penanganan yang telah dilakukan oleh lembaga-lembaga non pemerintah (NGO). Jadi, studi-studi yang belakangan lebih difaokuskan pada bagaimana intervensi yang telah dilakukan untuk menyikapi persoalan anak jalanan.

Studi yang agak makro dilakukan oleh Irwanto (1998) yang meneliti situasi anak jalanan di 12 kota besar di Indosesia. Studi ini dilakukan untuk merespon situasi kritis perekonomian saat itu, sehingga menjadi anak jalanan dapat dilihat sebagai pilihan terhadap kehidupan ekonomi. Studi lain dilakukan oleh Wahyu Nograha yang mengkaji Seksualitas Anak Jalanan. Studi ini mengambil fokus pada perilaku seksualitas anak jalanan yang ia katakan sebagai perilaku khas. Temuan mengejutkan dari studi ini bahwa hubungan seksualitas anak jalanan, yang mereka sebut esek-esek, itu rata-rata dimulai pada usia di bawah 12 tahun. Di sini, kategori hubungan sex tidak tunggal. Setidaknya ada dua kategori hubungan sex disamping esek-esek, seperti onani, dan homoseksual (sex oral dan sex anal). Berbeda dengan Wahyu Nugraha, Y. Argo Twikromo, mengkaji anak jalanan yang bekerja sebagai pemulung jalanan. Dalam studi ini Y. Argo T, mengkaji bagaimana peraturan pemerintah di suatu lingkungan kota telah mempengaruhi pandangan pemulung jalanan tentang realitas sosial budaya mereka (pemulung jalanan). Maka, temuan studi ini mengarah pada hubungan antara pemerintah dan pemulung jalanan yang dianggap sebagai hubungan yang mengucilkan dan memarginalkan keberadaan pemulung jalanan.

Anak jalanan pada hakekatnya sebuah kategori sosial yang bisa dibedakan ke dalam dua kelompok yaitu anak yang bekerja di jalan dan anak yang hidup di jalan. Anak yang bekerja di jalan dicirikan 
masih memiliki kontak dengan orang tua, mengakui keberadaan kedua orang tuanya dan tinggal dengan orang tuanya. Anak yang hidup di jalan, adalah anak yang sudah putus hubungan dengan orang tua mereka maupun keluarga. Kategori kedua ini, merupakan perwujudan dari anak-anak yang bekerja dan tinggal di sembarang tempat di jalanan seperti emper toko, taman kota, terminal, stasiun dan seterusnya.

Ada perbedaan definisi dan batasan umur yang diberikan terhadap anak jalanan. Pengertian umum yang sering digunakan bahwa anak jalanan adalah (1) anak-anak yang benar-benar hidup dan bekerja di jalanan dan ditelantarkan dan telah lari dari keluarga mereka (2) anakanak yang menjaga hubungan dengan keluarga mereka, tetapi menghabiskan waktunya di jalanan (3) anak-anak dari keluarga yang hidup di jalanan. Sedangkan dari sisi umur, menurut UU No. 4 tahun 1979, anak adalah mereka yang berusia di bawah 21 tahun. Departemen Sosial membatasi anak pada usia 7 - 15 tahun. Sementara Yayasan Kesejahteraan Anak Indonesia membatasi usia anak 6-15 tahun. Dan dalam The Minimum Age Convention on The Rights of The Chilld (1989), anak adalah mereka yang berumur 18 tahun ke bawah. Karena belum ada kesepakatan mengenahi umur anak, maka dalam penelitian ini mengambil batasan umur anak adalah 18 tahun ke bawah dengan alasan bahwa umur 18 tahun merupakan umur dari sekolah lanjutan atas. Dengan demikian, anak jalanan yang dimaksud dalam penelitian ini adalah anak-anak yang berusia 18 tahun ke bawah terdiri dari laki-laki dan perempuan dan hidup di jalanan. Batasan usia ini juga sesuai dengan batasan usia yang dikemukakan dalam Undang Undang Perlindungan Anak yang. menyebutkan bahwa anak adalah individu berusia di bawah 18 tahun.

Untuk menjadi anak jalanan, biasanya melewati proses. Anak yang baru terjun ke jalanan, belum mengenal dan dikenal siapapun di dunia barunya itu. Selain itu, mereka juga diliputi rasa kekhawatiran bila identitas dirinya diketahui orang lain. Untuk menjaga dan menghindari kekhawatirannya tersebut, mereka biasanya merubah identitas lamanya mulai dari mengganti nama, cara berpakaian maupun bahasa pergaulannya. Pergantian tersebut dilakukan dengan maksud untuk memutus rantai dengan masa lalunya sekaligus masuk dunia barunya. Ketika ia sudah berada di jalanan, ia menjelma dengan nama baru dan sebutan barunya. Anak-anak yang berasal dari pedesaan mengganti dengan nama-nama yang dianggap lebih modern, yang diambil misalnya dari bintang sinetron atau nama-nama yang sudah familier di telinga mereka seperti 
Alex, Roy, Iwan dan seterusnya. Proses penggantian ini sebenarnya bukan sekedar penggantian panggilan semata melainkan juga sebagai wahana menanggalkan masa lalunya, dan yang terpenting merupakan pernyataan untuk memasuki suatu dunia baru yaitu sebuah kehidupan jalanan. Dalam dunia pendidikan, anak jalanan termasuk dalam kelompok anak usia sekolah yang tereksklusi dan jarang mendapat perhatian serius dari pemerintah. Dalam konteks perundangan, mereka memiliki hak yang sama untuk memperoleh pendidikan, baik pendidikan umum maupun keagamaan. Di sinilah sebenarnya peran negara dituntut untuk menanganinya karena mereka pada hakekatnya juga anak bangsa.

\section{Pendidikan Keagamaan}

Ada dua istilah yang selalu berdampingan dan terkadang melahirkan pengertian yang rancu diantara keduanya yaitu pendidikan agama dan pendidikan keagamaan. Dua istilah ini perlu dibedakan dengan maksud bisa menentukan arah tujuan penelitian yang hendak dicapai. Pendidikan agama adalah pendidikan yang memberikan pengetahuan, keterampilan dan sikap peserta didik dalam mengamalkan ajaran agama pada semua jalur, jenjang dan jenis pendidikan. Pendidikan agama diberikan sebagai jawaban langsung dari tantangan yang tertuang dalam UU Sisdiknas, bahwa pendidikan di Indonesia bertujuan untuk berkembangnya potensi peserta didik agar menjadi manusia yang beriman dan bertakwa kepada Tuhan Yang Maha Esa, berakhlak mulia, sehat, berilmu, cakap, kreatif, mandiri dan menjadi warga Negara yang demokratis serta bertanggung jawab. Sementara dalam Peraturan Pemerintah No 55 tentang Pendidikan Agama dan Keagamaan dijelaskan bahwa pendidikan agama diberikan pada satuan pendidikan dan diberikan sekurang-kurangnya dalam bentuk mata pelajaran dengan tujuan berkembangnya peserta didik dalam memahami dan mengamalkan nilai-nilai agama yang mengimbangi penguasaannya dalam ilmu pengetahuan, teknologi dan seni. Dengan demikian pendidikan agama diharapkan mampu membangun watak dan kultur bangsa yang religius, tidak semata dalam aspek ritus dan peribadatan tetapi justru refleksi spirit keagamaan dalam seluruh perbuatan professional dan social masyarakat Indonesia.

Pendidikan keagamaan adalah pendidikan yang mempersiapkan peserta didik untuk menjalankan peranan yang menuntut penguasaan pengetahuan tentang ajaran agama dan/atau ahli ilmu agama dan mengamalkan ajaran agamanya. Dengan demikian, pendidikan keagamaan 
bertujuan untuk membentuk peserta didik yang memahami dan mengamalkan nilai-nilai ajaran agamanya dan/atau menjadi ahli ilmu agama yang berwawasan luas, kritis, kreatif, inovatif dan dinamis dalam rangka mencerdaskan kehidupan bangsa yang beriman, bertakwa dan berakhlak mulia. Merujuk pada pengertian ini, ada perbedaan mendasar antara pendidikan agama dan pendidikan keagamaan. Pendidikan agama diberikan sebagai upaya membina ketakwaan peserta didik dan mampu merefleksikan sikap dan tindak ketakwaannya dalam seluruh perbuatan profesi dan sosialnya. Sementara pendidikan keagamaan adalah jalur dan jenis pendidikan yang lebih memperbesar penawaran pelajaran agama, dengan tujuan membina calon ahli-ahli ilmu agama (Islam), yang tidak saja membentuk kepribadian religius pada dirinya, tetapi juga dapat memberikan pembinaan keagamaan pada orang lain. Maka tidaklah fair untuk mengkaji pendidikan keagamaan sebagaimana definisi di atas bagi kalangan anak jalanan. Maka yang dimaksud pendidikan keagamaan dalam penelitian ini adalah bagaimana praktek praktek pendidikan agama pada anak jalanan. Atau yang lebih tepat adalah bagaimana pengalaman pendidikan agama pada komunitas anak jalanan.

\section{TEMUAN : \\ Profil Anak Jalanan}

Sebagaimana dijelaskan di atas bahwa anak jalanan adalah anak yang berusia 18 tahun ke bawah, bekerja dan hidup di jalanan. Anak jalanan yang menjadi subyek penelitian adalah anak-anak yang memiliki beragam profesi seperti pengamen (menggunakan alat musik), pengemis (tanpa menggunakan alat), tukang sapu gerbong kereta api, penjual asongan (termasuk makanan kecil), punk, calo, tukang parkir. Berbagai jenis pekerjaan tersebut dilakukan dalam rangka bertahan hidup. Menurut pengakuan mereka, pilihan pekerjaan didasarkan pada beberapa pertimbangan, yakni pekerjaan itu secara teknis mudah dilakukan dan menghasilkan uang, tidak membutuhkan banyak tenaga, modal, peralatan, dan bekal keterampilan tertentu. Intinya, mudah mendapatkan uang dan bisa dilakukan kapan saja. Karena itu, pilihan pekerjaan terpopuler di kalangan anak jalanan jatuh pada mengamen.. Jenis pekerjaan yang dirasa sulit seperti berjualan (asongan atau kaki lima), kurang diminati karena memerlukan modal, usaha keras, keterampilan, dan peralatan tertentu, serta tidak bisa dilakukan sembarang waktu dan tempat. 
Dilihat dari penghasilan perhari, cukup bervariasi, tergantung usaha dan lamanya melakukan pekerjaan tersebut. Tetapi, di kalangan anak jalanan, mereka mengenal istilah keberuntungan. Jika nasib sedang baik, bisa mendapat uang lebih banyak dan sebaliknya. Prinsip yang mereka gunakan "Yang penting bisa makan di hari itu". Dari sisi tempat melakukan pekerjaan, juga bervareasi, ada yang di lampu merah, terminal bus, stasiun kereta api, pusat perbelanjaan, dan masuk ke kampung-kampung. Untuk yang terakhir, memiliki alasaan tersendiri misalnya menghindari aparat keamanan. Mereka menyadari akan semakin gencarnya pengejaran aparat (Tramtib, Dinas Sosial dan Polisi) yang terus menerus ingin membersihkan anak jalanan dari sudut kota besar. Maka dengan mengamen masuk kampung, mereka merasa lebih aman.

Kategori anak jalanan yang menonjol dan agak berbeda adalah kelompok punk. Punk merupakan kumpulan anak-anak jalanan yang biasa mangkal di suatu daerah perkotaan. Kelompok ini terbentuk lebih karena kesamaan pandangan dan selera. Usia mereka juga lebih dewasa misalnya 15 tahun sampai di atas 18 tahun. Ciri khas kelompok ini lebih menonjol dari sisi gaya dan penampilan, mulai dari pakaiannya yang nyleneh dan terkesan urakan, dilengkapi rantai di celana, menggunakan anting di telinga, bibir hidung dan puser. Anak-anak punk juga biasa menggunakan tato di badan dan mengecat rambutnya pada beberapa bagian. Dari segi potongan rambut, kelompok ini juga lain dari model/ potongan rambut pada umumnya. Anak-anak punk tidak membentuk organisasi yang formal dan terstruktur, karena itu tidak ada yang disebut pemimpin dan anggota. Siapapun yang ingin bergabung, mereka tinggal berkumpul di tengah lingkungan mereka dan bersosialisasi dengan cara memperkenalkan diri. Mereka disatukan dalam satu kesadaran untuk berbagi dengan sesama dan keinginan untuk "ngumpul." Anakanak punk sangat mengutamakan solidaritas, karena itu semangat membela sesama sangat tinggi. Mereka memiliki jaringan di berbagai kota besar. Komunikasi di antara mereka terjalin baik dalam konteks kelompok maupun perseorangan untuk datang atau "kumpul" dengan anak-anak punk di kota lain. Pada setiap event yang diadakan di sebuah kota, misalnya, maka anak-anak punk dari kota lain diundang hadir, dan mereka semua merasa perlu untuk hadir. Bagi anak-anak punk, kegiatan, kehidupan pribadi dan pendidikan keagamaan adalah wilayah kepentingan pribadi yang tidak ada hubungannya dengan kegiatan ke-punk-an. Tidak ada satu pun kesepakatan di antara punk 
tentang perilaku keagamaan, karena persoalan agama adalah menjadi urusan pribadi masing-masing.

\section{Sebab Menjadi Anak Jalanan}

Ada kesulitan untuk mengidentifikasi jumlah anak jalanan pada masing-masing lokasi penelitian. Hal ini disebabkan karena keutuhan kelompok anak jalanan sangat rentan oleh penangkapan aparat dan Dinas Sosial. Bahkan demi kelangsungan hidup sebagai anak jalanan, di sebagian wilayah justru mengambil pola hidup perseorangan. Yang masih bertahan dalam bentuk kelompok, mereka biasanya sudah tergabung dalam binaan rumah singgah yang di motori oleh masyarakat yang peduli terhadap anak jalanan. Di kota-kota besar di Jawa, pada saat penelitian dilakukan sulit menemukan anak jalanan berkeliaran karena mereka yang masih berada di luar rumah singgah dan pembinaan Dinas Sosial takut keluar di sembarang waktu. Sementara untuk kembali ke rumah (bagi yang masih punya orang tua) juga sangat tidak mungkin karena alasan tertentu.

Mereka menjadi anak jalanan memang karena tidak bisa hidup di rumah. Faktor orang tua, menjadi alasan paling dominan anak terjun ke jalanan. Orang tua yang berpisah karena perceraian, ditinggalkan suaminya begitu saja, kemiskinan ekonomis dan ketegaan merupakan pemicu tercabutnya anak dari keluarga. Di antara faktor-faktor kondisi orang tua tersebut pada dasarnya berimbang menjdi penyebab anak menjadi anak jalanan. Banyak anak jalanan obyek penelitian yang masih belia (usia kelas 2-3 Sekolah Dasar) harus bekerja ikut membantu ekonomi keluarganya, sebagai pengamen atau pemulung sampah. Pertanyaan yang mengganggu kita sebenarnya apakah orang tua yang memaksa anaknya untuk bekerja demi ekonomi keluarga tersebut termasuk eksploitasi anak? Secara kasat mata, pemaksaan orang tua seperti itu mirip dengan eksploitasi oleh orang tua sendiri. Anak yang masih sekolah di SD harus membantu orang tua mencari nafkah. Yang agak berbeda adalah tidak punya orang tua. Anak yang ditinggal orang tuanya kemudian hidup bersama teman-temannya kemudian mangkal di suatu tempat. Berbagai hal ia lakukan seperti disuruh berjualan oleh pedagang yang mangkal di tempat tersebut atau mengemis.

Faktor-faktor menjadi anak jalanan sebagaimana telah disebutkan tidak berbeda dengan hasil temuan-temuan lainnya. Aan T. Subhansyah $\mathrm{dkk}$, misalnya, menyebutkan bahwa persoalan kemiskinan ekonomi 
keluarga sering disebut sebagai penyebab utama munculnya anak jalanan. Tetapi menurutnya ada faktor lain yang saling terkait, seperti kekerasan dalam keluarga, perpecahan dalam keluarga, atau pengaruh lingkungan. Tekanan ekonomi akibat kemiskinan membuat orang tua mengharuskan anak-anak mereka turut menanggung beban keluarga. Atau, anak-anak yang menyadari kondisi keluarganya miskin, kemudian ikut membantu memenuhi kebutuhan keluarga dengan cara bekerja, baik di jalanan atau di tempat lainnya. Ada pula anak-anak dari keluarga miskin tersebut yang turun ke jalan setelah mendapat kekerasan dari orang tua atau karena masalah lain seperti perceraian orang tua.

Penyebab lain adalah faktor lingkungan sosial. Anak yang hidup di lingkungan mayoritas pekerja jalanan, membentuk pandangan anak terhadap pilihan kehidupan mereka. Pengalaman sehari-hari seorang anak menjdi alternatif pertama ketika mereka harus menentukan pekerjaan. Disamping mereka sudah mengenal dunia tersebut, mereka tidak akan menghadapi kesulitan berarti dalam menjalankan pekerjaan.

Faktor pembawaan, misalnya anak yang ingin hidup bebas, ternyata bisa menjadi penyebab anak jalanan. Kepribadian anak yang lebih suka hidup bebas, tidak mau diatur, potensial menjadi anak jalanan. Tetapi ini masih perlu penelitian lebih mendalam dan belum berani manjadikan faktor kepribadian ini sebagai penyebab anak menjadi anak jalanan. Betapapun, masih ada alasan lain ketika anak menyebut faktor kepribadian yang ingin bebas tersebut. Misalnya, pada awalnya anak tersebut ikut bekerja dengan teman atau orang lain. Tetapi kemudian karena sesutu hal, seperti penghasilannya sedikit sementara tenaga dan waktu yang dibutuhkan banyak, akhirnya dia mencoba pekerjaan lain yang lebih mudah, seperti mengamen dan sejenisnya. Lama kelamaan dia merasa nyaman dan gampang menghasilkan uang dengan pekerjaan barunya tersebut yang akhirnya menjadi pilihan.

\section{Bentuk-Bentuk Pendidikan Keagamaan}

Salah satu alternatif yang diharapkan dapat membantu penyelesaian anak jalanan adalah melalui pendidikan agama. Hal ini diakui beberapa kalangan baik dari Dinas sosial, Departemen Agama (Kandepag, melalui Kasie Penamas), Pengelola rumah singgah dan beberapa anak jalanan yang diwawancarai. Bagi Dinas sosial pembinaan anak jalanan tidak cukup dengan pendekatan keterampilan kerja semata, tetapi justru yang terpenting adalah pendekatan melalui mental keagamaan, atau 
lebih tepatnya pendekatan pendidikan agama. Karena melalui pendidikan agama ini anak jalanan bisa diperkenalkan suatu kehidupan yang lebih hakiki yaitu kehidupan akherat. Dengan cara ini diharapkan mempunyai dampak positif bagi penyelesaian anak jalanan.

Dari perspektif Departemen Agama, pendekatan ini sebenarnya tantangan ke depan untuk lebih bisa berbuat secara kongkrit terhadap pelayanan pendidikan keagamaan yang selama ini belum menjadi prioritas. Bukan hanya itu, pendidikan keagamaan bagi anak jalanan harus ditangani secara langasung karena kalau dibiarkan tidak akan terlaksana. Ini bedanya dengan pendidikan keagamaan yang sudah berada di lembaga-lembaga pendidikan, kalau toh mereka dibiartkan sudah ada yang mengurusi. Ini yang barangkali Departemen Sopsial menjadi tidak bisa bekerja sendiri melainkan perlu mitra dengan Departemen Agama. Departemen Agama pada dasarnya punya perangkat yang memadai, misalnya penyuluh agama yang tersebar di berbagai kecamatan, baik dari penyeuluh agama yang statusnya pengawai negeri maupun yang honorer. Tapi memang selama ini belum begitu banyak menyentuh pada kalanagan anak jalanan, mereka, para penyuluh lebih banyak melakukan pembinaan justru pada lembaga-lembaga yang sudah mapan, seperti Majelis Taklim, TPQ, Panti Asuhan sementara pembinaan terhadap anak jalanan dianggap pekerjaan yang kurang menantang.

Melalui Dinas Sosial pendidikan keagamaan anak jalanan mulai menapak. Dinas Sosial memberikan siraman pendidikan keagamaan terhadap anak-anak yang terjaring razia melalui ceramah keagamaan yang diberikan oleh tenaga penceramah yang disediakan sendiri oleh Depsos. Sementara isi dari ceramah keagamaan itu berkisar pada pentingnya hidup setelah mati nanti. Diharapkan dengan memperkenalkan hidup setelah mati, anak jalanan bisa dibangunkan kembali nilai-nilai agamanya yang pernah mereka kenal dan alami sebelumnya.

Gambaran tentang bentuk pendidikan keagamaan pada anak jalanan tidak bisa dilihat dari kaca mata pendidikan normal. Artinya, ada stuktur pembelajaran yang jelas, guru yang pasti, tempat yang permanen dan seterusnya. Sebagaimana karakter anak jalanan, mereka tidak menempati suatu tempat yang tetap melainkan berpindah-pindah, maka kemungkinan untuk mendapat pendidikan keagamaan juga terbatas. Kondisi ini diperkuat oleh lembaga-lembaga pendidikan keagamaan Islam yang ada, belum memberikan pelayanan yang fleksibel (mayoritas). Para pelaksana pendidikan keagamaan masih menggunakan kerangka 
bahwa untuk belajar agama/mengaji harus mendatangi guru yang tentu saja ini menjadi sulit dilakukan oleh anak jalanan.

Bagi anak jalanan, pendidikan keagamaan sebenarnya bukan hal asing sama sekali. Mereka sebagian sudah pernah mendapatnyabaik melalui orang tua atau lingkungan dimana mereka tinggal sebelum menjadi anak jalanan. Kisah-kisah di sekitar mereka menunjukkan bahwa pendidikan keagamaan sudah mereka kenal dan alami. Tetapi kemudian setelah mereka menjadi anak jalanan, pendidikan keagamaan seolah-olah terpisah dengan kehidupan mereka. Pendidikan keagamaan tidak lagi menjadi pemikiran dan kebutuhan dalam kehidupan jalanan.

Sasaran penelitian ini membidik dua jenis anak jalanan; anak jalanan yang benar-benar liar dalam arti hidup di jalan dan anak jalanan yang sudah mendapat pembinaan melalui rumah singgah. Untuk anak jalanan yang sudah mendapat pembinaan di rumah singgah, mereka sedikit banyak sudah belajar agama. Mereka sudah mulai muncul keinginan dan kesadaran belajar agama. Akan tetapi, sekali lagi ini membutuhkan perjuangan dan proses yang panjang.

Sementara pendidikan yang dilakukan pada rumah singgah cukup bervariasi. Ada yang menyediakan guru secara khusus, ada pula yang memberi kesempatan anak jalanan untuk mengaji di lingkungan sekitar. Tetapi ada juga rumah singgah yang tidak menyediakan guru dan lingkungannya tidak tersedia guru, mereka membiarkan siapa saja yang datang ke rumah singgah tersebut untuk memberikan pendidikan keagamaan. Jenis dan isinya terserah pada mereka yang akan memberikan pendidikan keagamaan. Rumah singgah yang demikian pada dasarnya bukan berorientasi pada pembinaan keagamaan melainkan pada pembinaan keterampilan kerja dan pendidikan pada umumnya. Di rumah singgah jenis ini, mereka yakin betul bahwa pendidikan keagamaan akan diperoleh di sekolah formal. Karena memang prinsip yang dianut dalam rumah singgah ini adalah mengembalikan anak pada pendidikan dan pulang ke rumah.

Pelayanan pendidikan keagamaan anak jalanan pada ummnya masih minim, karena ada persoalan keterbatasan sumbere daya, baik sumber daya manusia maupun sumber daya keuangan. Untruk menjangkau anak jalanan yang sudah berada di rumah singgah saja masih diperlukan upaya serius agar mereka terpenuhi pendidikan keagamaannya. Terlebih lagi bagi anak jalanan yang liar, dibutuhkan tenaga super ekstra agar mereka mau menerima dan menganggap pendidikan keagamaan sebagai 
kebutuhan. Maka, dalam keserbakekurangannya tersebut, pendidikan keagamaan anak jalanan baru menyentuh pada aspek-aspek dasar tentang keimanan, akhlak, belajar membaca Iqra/al-Qur'an. Alasan mendasari mengapa jenis ini yang pilih, karena pertimbangan keragaman latar belakang, mulai putus sekolah, broken home, anak yatim, dan latar belakaang pendidikan yang tidak sama. Kondisi ini juga membawa problem tersendiri dalam memberikan pelayanan agama bagi anak jalanan, karena jika tidak hati-hati dan bertahap anak jalanan yang sudah tergabung di rumah singgah akan lari dan kembali ke jalan. Maka tahapan yang diambil oleh rumah singgah adalah bagaimana anak jalanan tetap mau bergabung di rumah singgah, kemudian ikut belajar dan shalat berjamaah di masjid.

\section{PENUTUP}

\section{Kesimpulan}

1. Anak jalanan yang menjadi sasaran penelitian adalah anak jalanan yang tinggal di rumah singgah dan anak jalanan yang masih liar.

2. Penyebab mereka menjadi anak jalaanan yang terbesar adalah karena pertama, kondisi orang tua yang tidak harmonis dalam membina keutuhan keluarga. Kedua, kemiskinan ekonomis orang tua. Ketiga, lingkungan sosial.

3. Tidak ada jenis dan bentuk pendidikan kegamaan secara khusus yang diberikan kepada anak jalanan, demikian juga lemnbaga dan perorangan yang terlibat.

4. Dilihat dari jenisnya, pendidikan keagamaan pada anak jalanan berkisar pada pembinaan mental yang berisi keimanan dan akhlak, belajar membaca Iqra/al-Qur'an, dan belajar shalat.

5. Sebagian anak jalanan merasa perlu pendidikan keagamaan, namun mereka tidak tahu harus belajar di mana dan dengan siapa.

\section{Rekomendasi}

1. Perlu ada formula kebijakan Departemen Agama yang khusus menyentuh pendidikan keagamaan anak jalanan.

2. Perlu pembekalan khusus bagi penyuluh agama yang ada di Kandepag seperti keterampilan pendampingan dalam bidang pendidikan keagamaan sehingga mampu menyentuh anak jalanan, khususnya anak jalanan yang masih liar. 
3. Untuk pendidikan keagamaan bagi anak jalanan yang masih liar, perlu dibangun ruang-runag khusus yang fleksibel, yang bisa menyesuaikan dengan tempat dimana anak jalanan mangkal.

4. Perlu kerja sama dengan unit terkait seperti Dinas Sosial khususnya Bidang Rehabilitasi Anak, yang selama ini sudah menangani anak jalanan.

\section{SUMBER BACAAN}

Antariksa, Intelektual, Gagasan Subaltern, dan Perubaban Sosial, http://kunci.orid/ esai/misc/antariksa-subaltern.htm

Azis Ali Moh (ed) (2005): Dakwah Pemberdayaan Masyarakat : Paradigma Aksi Metodologi. Yogyakarta, Pustaka Pesantren

Chaniago A. Andrinof (2001): Gagalnya Pembangunan Kajian Ekonomi Politik terbadap Krisis Indonesia. Jakarta, LP3ES.

Creswell, John W. (1994), Researcb Design Qualitative \& Quantitative Approaches, California, SAGE Publication.

Darmaningtyas (2005): Pendidikan Rusak-Rusakan. Yogyakarta, LKiS.

Gelandangan Pandangan Ilmuwan Soaial (1984): Jakarta, LP3ES

Kymlicka Will (2003): Kenvargaan Multikultural. Jakarta, PT Pustaka LP3ES.

Meighan Roland (1981): A Sociology of Educating. Holt, Rinehard and Wiston Ltd,

Majelis Permusyawaratan Rakyat RI, Panduan Pemasyarakatan Undang Undang Dasar Negara Republik Indonesia Tabun 1945 sesuai dengan urutan Bab, Pasal, dan Ayat, Sekretarian Jenderal MPR RI

Neuman, Lawrence W (1991): Social Researcb Metbods Qualitative and Quantitative Approaches. USA, Allyn \& Bacon.

Nurharjadmo, Wahyu (1999): Seksualitas Anak Jalanan. Yogyakarta, Pusat Penelitian Kependudukan Universitas Gajah Mada.

Rosyada, Dede (2005): Pendidikan Keagamaan dalam Sistem Pendidikan Nasional, Makalah disampaikan pada Workshop "Pengembangan Lembaga Pendidikan Keagamaan", Lembaga Penelitian Universitas Negeri Jakarta-Badan Litbang dan Diklat Departemen Agama, 27 Juli 2005

Twikromo, Argo. Y (1999): Gelandangan Yogyakarta Suatu Kebidupan dalam Bingkai Tatanan Sosial-Budaya "Resmi" Yogyakarta, Univ. Atma Jaya (1999): Pemulung Jalanan Konstruksi Marginalitas dan Perjuangan Hidup dalam Bayang-Bayang Budaya Dominan. Yogyakarta, Media Pressindo.

Undang Undang Sistem Pendidikan Nasional Nomor 20 Tabun 2003, 2005, Sinar Grafika, Jakarta 